\author{
Марина Ткачук \\ Інститут української мови \\ Національної академії наук України \\ Київ, Україна \\ ORCID: 0000-0002-4165-7741; e-mail: tkachuk_maryna@ukr.net
}

\title{
Ідіолект у структурі переселенської острівної говірки
}

\begin{abstract}
Реферат: Статтю присвячено аналізу фонетичних та фонетико-граматичних рис, що виокремлюють на загальноговірковому тлі ідіолекти українців зі східної діаспори, які проживають у полімовному середовищі в Башкирії, але зберігають питомий мовний код, активно користуючись українською діалектною мовою в побуті. Джерельну базу дослідження формують записи спонтанного діалектного мовлення мешканців с. Золотоношка Стерлітамакського району та с. Степанівка Аургазинського району Республіки Башкортостан (РФ). Встановлено, що на тлі відносної одноманітності мовних рис говірок с. Золотоношка і с. Степанівка на рівні окремих ідіолектів вирізняються особливості, що властиві лише для мовлення конкретного діалектоносія або ж мають у мовленні конкретного носія говірки більший чи менший ступінь вияву. Маркери ідіолекту зазвичай мають ареальну прив’язку до конкретної мовної системи в материнському ареалі.
\end{abstract}

Ключові слова: українські діалекти, переселенська говірка, діалектне мовлення, гетерогенна говірка, ідіолект.

\begin{abstract}
Idiolect at the structure of resettled isolated dialect. The article deals with an analysis of phonetic and phonetic-grammatical features that distinguish idiolects spoken by Ukrainians from the Eastern Diaspora in Bashkortostan, presented against a common dialectal background. Records of spontaneous dialectal speech of Ukrainians from Zolotonoshka village, Sterlitamak district, and Stepanivka village, Aurgazin district, Republic of Bashkortostan (Russian Federation), represent the source of the research. The Ukrainian speakers in question live in a polylingual environment but maintain a specific language code while actively using Ukrainian dialects in everyday life. In these resettled micro-dialects with a poly-dialectal base, the formation of a new homogeneous dialect depends on maintenance or transformation of specific idiolects spoken by different dialectal speakers. Against the background of the relative uniformity of Zolotonoshka and Stepanivka language features, there are attributes which only mark particular idiolect, or, more often, have a degree of manifestation in the speech of the various speakers. Idiolect markers are usually area-related to a specific language system of the maternal dialects.
\end{abstract}

Keywords: Ukrainian dialects, resettled dialect, dialectal speech, heterogeneous dialect, idiolect.

Переселенські говірки як діалектний тип дослідники виокремлюють на тлі основного діалектного масиву мови на підставі співвідношення середовища їхнього формування і нинішнього побутування: вони змінили свою локалізацію 
з огляду на низку причин і тепер функціонують у віддаленні від свого вихідного материнського ареалу. За типом діалектної основи переселенські говірки можуть бути моно- або полідіалектними. В останньому випадку мовці $є$ носіями чи нащадками носіїв різних говірок у континуумі материнському.

У таких полідіалектних переселенських говірках важливу роль відіграють окремі ідіолекти, від збереження або трансформації яких залежить, чи постане однорідна новосформована говірка (див. також Фроляк 2002, 207). Ідіолект - це «мовна практика окремого носія мови; сукупність формальних і стилістичних ознак, що вирізняють індивідуальну мову» (Срмоленко, Бибик, Тодор 2001, 67); див. також: (Срмоленко 2007, 676-677; Ставицька 2009). Зазвичай ідіолекти розглядають у контексті лінгвостилістики або соціолінгвістики; з погляду діалектології дослідженню ідіолектів різних українських говорів та різної материнської основи присвятили свої дослідження П.Ю. Гриценко, Л.Д. Фроляк, К.Д. Глуховцева, О.П. Кумеда та інші лінгвісти; у російському мовознавстві відома праця К.В. Іванцової Феномен мовної особистості (Иванцова 2002) тощо.

У нашому дослідженні ми зосередимося на аналізі окремих ідіолектних рис у мовленні носіїв українських острівних говірок Башкирії, що проживають у полімовному та полікультурному ареалі, контактуючи в межах населеного пункту з росіянами, башкирами й татарами.

Перші українські поселення в Башкирії почали виникати ще у XVIII ст., коли царський уряд видав указ, що стимулював переселення на Передуралля, в Оренбурзьку губернію, українців, адже зведення й функціонування оборонних фортець на нових рубежах Російської імперії потребувало людей (Бабенко 2011, 10). Як зазначав відомий археограф та історик книги П.М. Попов, у 1742 р. на Приураллі було зареєстровано 509 українських родин (Попов 1999, 24-25). Водночас основна хвиля переселення тривала впродовж XIX ст. та на початку XX ст.; іï основною причиною була соціально-економічна й політична ситуація в Росії. Після Столипінської реформи в 1906 р. міграція українського населення на Схід значно пожвавилася (Бабенко 2011, 10-11). Однак здебільшого це були самовільні переїзди, селяни не отримували допомоги від держави, а інколи - навіть дозволів. Зокрема, упродовж 1896-1905 рр. було зареєстровано 216,7 тис. самовільних переселенців. Ці показники щороку зростали, сягнувши 2 млн. осіб до Першої світової війни (УСД, 11).

Башкирські села Золотоношка і Степанівка ${ }^{1}$ були засновані наприкінці XIX ст.

Село Золотоношка Стерлітамакського району (станом на 2010 р. у Золотоношці проживало 563 особи (ЧНБ, 123), 57\% з яких - українці) утворене першопоселеннями Золотоношка, Малодєєвка та Полтавка; наразі ці топоніми збереглися як назви частини села, де мешкають здебільшого нащадки вихідців із різних українських територій: із колишньої Полтавської губернії, зокрема Золотоніського та Констянтиноградського повітів (нині це Драбівський та Золотоніський р-ни Черкаської обл. та Красноградський р-н Харківської обл.). Зауважимо, що існувала

1 Записи українського мовлення українських острівних говірок у Башкортостані здійснено в 2012 p. 
традиція: переселенці часто зберігали назву села - своєї малої ба́тьківщини: от

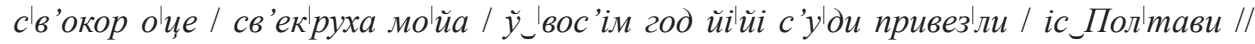

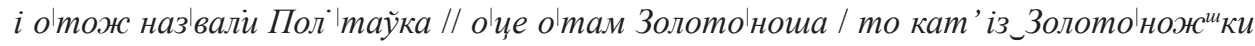
де_то // a оие |Д'ейеўс'ка / йа не_зиайу //2. Здебільшого це лише узагальнена вказівка на поселення пращурів переселенців в Україні; крім того, змінилися кордони й територіально-адміністративний устрій, що ускладнює точне встановлення вихідної говірки. Рідше діалектоносії точно ідентифікують населений пункт, звідки відбулося переселення, що уможливлює глибший лінгвістичний аналіз - на різних часових зрізах з урахуванням сучасного стану материнської говірки. Зокрема, під час інтерв’ювання інформанти неодноразово визначали материнську говірку своїх батьків - Жорнокльови, Безбородьки, Нехайки, Безпальче, Гельмязів (Черкаська обл.); Вознесенське (Харківська обл.) тощо. Наприклад: м’ $і$ й

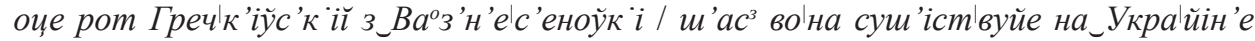

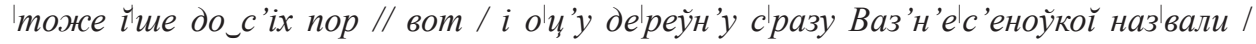
n’іудерреўн'i // там Золотоношка на ту стторону / на_и'у Ваз'н'еІс'еноўка //

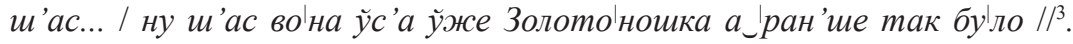

Мешканці колишньої Малої Дєєвки, що наразі є частиною с. Золотоношка, нащадки вихідців із Київської губернії, однак згідно з адміністративним устроєм початку XIX ст. до неї також належали північні райони Черкаської обл.: ну Малад'ейеўка иче |кийіўс'к'i / бу|ли // йак йіх / |кийіўс'к'i трубол'готи нази вали //

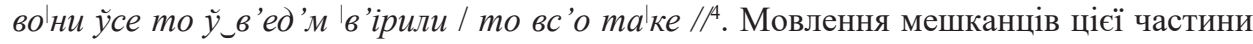
Золотоношки, як зауважують самі селяни, відрізняється від мовлення решти односельців лише окремими рисами.

Башкирське село Степанівку Аургазинського району в XIX ст. (за даними офіційного перепису населення 2010 р., у Степанівці проживала 381 особа (ЧНБ, 24-25), $з$ них українців - 39\%) заснували переселенці із Сумського повіту Харківської губернії: Ну прад’іди пере йіхали йакрасз оџие / Сумс'ка... / Сумс'кий

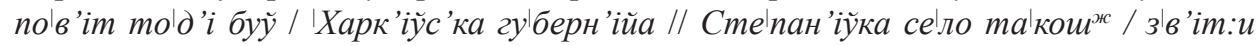
вони і перейіхали // ну / фактично усс'i зв'іт':iاл'а // перейіхали ну там у нас /

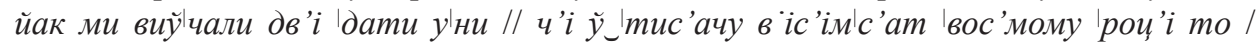
'топто сто д'ваи'ат' n' “й' 'рок’іў 'тому фак'тич'но у'же 'буде на_насттупний $p^{\prime} i \kappa / / /^{5}$. У материнському ареалі населені пункти, звідки відбулося переселення, розташовані в ареалі слобожанського говору, близько до ізоглоси, що відділяє його від середньонаддніпрянських говірок (АУМ, 1, к. IX).

Отже, основний масив населення обстежених переселенських говірок - носії південно-східного наріччя української мови, зокрема середньонаддніпрянських говірок давньої формації (Золотоношка) та контактних із ними слобожанських говірок (Степанівка) (АУМ, 1, к. IX); однак на різних структурних рівнях вони, звичайно, мають відмінності.

\footnotetext{
2 Інф.: Хижниченко Марія, 1934 р. н.

3 Інф.: Градська Галина Миколаївна.

4 Інф.: Хижниченко Григорій.

5 Інф.: Юнак Олександр Іванович, 1969 р. н.
} 
Питання полягає в тому, наскільки збережені ці відмінності в ідіолектах українців, які проживають в одному селі, та наскільки можна вважати справедливим твердження про «поступове стирання діалектних особливостей мови різних груп, які переселилися 3 різних регіонів України», та виформування «загального місцевого діалекту української мови, серед якого можна було виокремити локальні говірки», як зазначають дослідники-українознавці в Башкортостані (Бабенко 2011, 14). Текстовий корпус, сформований на основі записів діалектного мовлення, дає змогу здійснити такий аналіз. Адже, як зазначає П.Ю. Гриценко, «з двох основних інформаційних складових у вивченні ідіолектів тексту і мовного довкілля - досі спостереження зосереджують переважно на текстові як конкретному об’єктові, до якого можна застосувати різноманітні дослідницькі прийомі та процедури...» (Гриценко 2007a, 16). Такий аналіз дозволяє виділити деякі диференційні риси, якими вирізняються окремі ідіолекти на тлі решти ідіолектів, що складають переселенську говірку.

Зупинимося на деяких фонетичних та фонетико-граматичних рисах, які виокремлюють ідіолекти мовців на загальному тлі мовлення відповідного соціуму.

Однією 3 визначальних фонетичних рис середньонадніпрянського говору є зміна ненаголошеної фонеми [е] (рідше [i]) в [е", [и] (АУМ, 1, к. 40-44; Гриценко 2007b, 601); про те, що така зміна артикуляції властива більшості середньонаддніпрянських говірок, зазначає й Г.І. Мартинова в грунтовному дослідженні фонетики цього ареалу (Мартинова 2003, к. 5, 6). У зразках діалектного мовлення, записаних від різних інформантів у с. Золотоношка та Степанівка, такий перехід варіативний, простежується різною мірою в різних інформантів. Хоча в говірці с. Золотоношка перехід [е] в [и] подекуди може бути не дуже сильним й існувати на тлі збереження [е] в ненаголошеній позиції чи навіть переходу [и] в [е], що характерно для західної зони середньонаддніпрянського діалекту та східних полтавських говірок, проте в різних ідіолектах ця риса виявляється сильніше, ніж у мовленні інформантів с. Степанівка.

Так, в ідіолекті Хижниченко Марії, 1934 р. н. (материнська говірка с. Золотоношка, № 587 АУМ, 1) здебільшого зберігається етимологічний [и] або

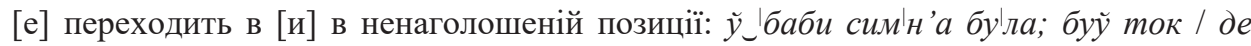

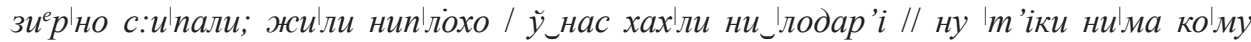

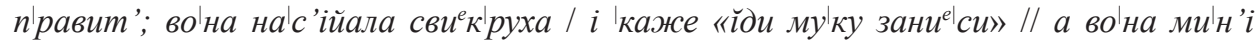

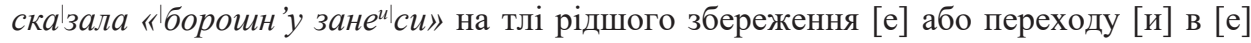
у так само слабкій позиції: 'бап ${ }^{6} к а$ бу'ла пре_памйат'i.

Зауважимо, що ця риса - збільшення функціонального навантаження фонеми [и] - властива й для ідіолекту сина Марії Хижниченко: б|рали 'тоже г'роши за_ие / жирипц'а да'вали 'л’уд’ам.

В ідіолекті Градського Олександра Федоровича, 1954 р. н. (материнська говірка - с. Вознесенське, Харківська обл.) перехід [е] в [и] виявляється не так

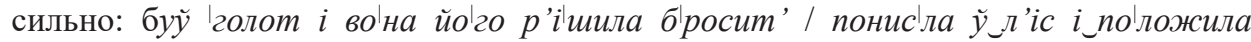

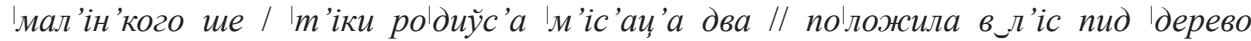

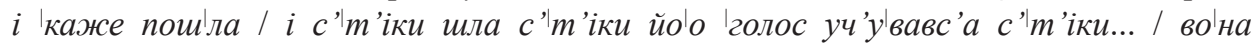
'каже ниґмог'ла 'витерп'іт' вир|нулас' $i$ забрала його; на тлі збереження [е] чи його переходу в [i]: очие ми|н'i 'саме інте ресно / йак так ота|ка 'поч ва шо / ми 


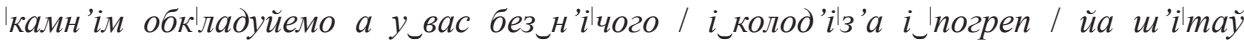

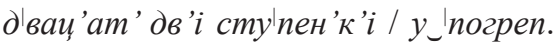

Натомість в ідіолекті Гречко Марії, 1939 р. н. (материнська говірка - Безбородьки, Драбівський район, Черкаська обл.) зауважено частіше збереження етимологічного [е] в слабкій позиції та частий перехід [и], [i] в [e]: nelduйде /

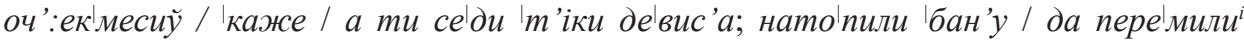
йіх / шоб не_пустит' та|ких г'р'аз'н'іх.

В окремих ідіолектах говірки Степанівка відзначено не лише збереження [е] у слабких позиціях, а й частіший перехід [и] > [e]: не_бол'но же'вем; не_бу'ло

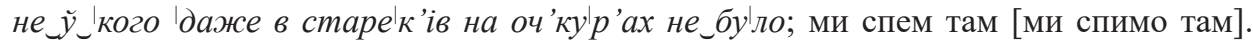
Загалом у мовленні діалектоносіїв, що проживають у Степанівці, функціональне навантаження фонеми [и] нижче (хоча перехід [е] в [и] також спорадично фіксуємо), ніж у мовленні мешканців Золотоношки, материнськими для якої виступають середньонаддніпрянські говірки.

Маркером ідіолекту в українських говірках Башкирії $є$ так зване «акання» перехід ненаголошеного [о] в [а]. На тлі загальної тенденції, що передбачає збереження в ненаголошеній позиції протиставлення [а] : [о], як і в материнських говірках (АУМ, 1, к. 71), у мовленні окремих діалектоносіїв відзначено більше виявлення «акання», а саме субституція [o] $\rightarrow$ [а], зумовлена впливом норми російської мови, з носіями якої українці Башкирії активно контактують. Ця риса більше притаманна мовленню тих діалектоносіїв, які обіймали чи обіймають офіційні посади і змушені часто послуговуватись російською мовою. У таких

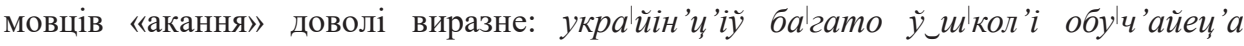

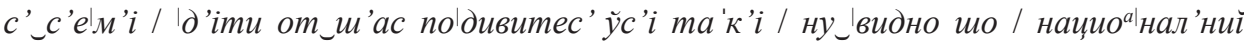
калар'іт сахрафнивс'а / вот //; рабботайу вос'мий гот / шо получч'айец'а? / ну / ат|л'іч'ник абраза'ван 'ийа P'іс публ'ік'i Башкартастан // (Гречко Ольга Петрівна, директор школи с. Золотоношка).

Одна 3 характерних рис консонантизму середньонаддніпрянських та багатьох слобожанських говірок - альвеолярний [л`] у позиції перед голосними $u, e, o, y$, $a$ та перед приголосними, і така вимова притаманна окремим мовцям у переселенських говірках Башкирії. Загалом у мовленні золотоношців його вияв сильніший порівняно 3 мовленням мешканців с. Степанівка: на підставі вибірки обсягом 4 а.а. транскрибованих діалектних текстів 3 кожного населеного пункту встановлено співвідношення 197 випадків вживання [л`] проти 33 в ідіолектах Золотоношки та Степанівки відповідно. Наприклад, в ідіолекті вже згадуваної Марії Хижниченко (говірка с. Золотоношка) ця риса виявляється дуже сильно: вони_ж сттопом 'йіхали

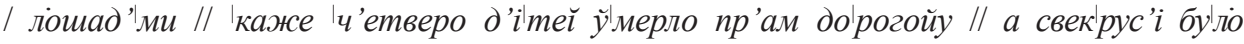

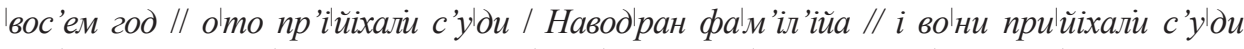

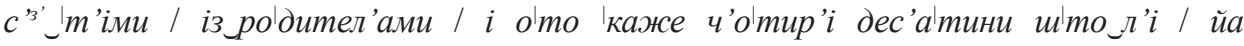
не_зинайу / 'каже / зем'л'і нам даІли тут 'каже Башікир'ійі // i о'то так / ну оџие Наводран / вони ўлас / були йак зажиточ'н'i. Тоді як у ії доньки Скрипник Тетяни Григорівни, 1956 р. н., та іï чоловіка Григорія Павловича Скрипника, 1953 р. н., цієї риси не простежено зовсім (зауважимо, що родина мешкає разом).

У говірці с. Степанівка альвеолярний [л`] спорадично вживається в мовленні окремих інформантів на тлі суцільного вживання [л] звичайного: Булі но / йак?.. / 
тод’i_и... // корова буліа / овечки були / свинец держсали (Калітаєва Зінаїда Гнатівна, 1925 р. н.; ареал материнських говірок - колишня Харківська губернія, с. Степанівка).

Підкреслимо, що зона трансформації опозиції [л] : [л’] $\rightarrow$ [л`] : [л’] у середньонаддніпрянських говірках доволі широка (Мартинова 2003, к. 25); сюди потрапляють і села Золотоношка, Нехайки, Гельмязів, говірки яких є материнськими для діалектоносіїв з башкирської Золотоношки; див. також тексти, записані в українській Золотоношці (ГЧ, 78-83). Натомість у слобожанських говірках вияв [л] та [л`] є паралельним (Гриценко 2007c, 632; Бевзенко 1980, 238).

Ступінь м'якості шиплячих, яку як фонетичну особливість центральної частини середньонаддінпрянського говору виокремлював ще К. Михальчук (1872 р.), у різних позиціях докладно проаналізовала Г.І. Мартинова (Мартинова 2003, 147-164). Ця риса в мовленні окремих українців Башкирії є дуже варіативною, проте м'якшення [ж] перед [а] в дієсловах 3 ос. мн. властиве лише окремим

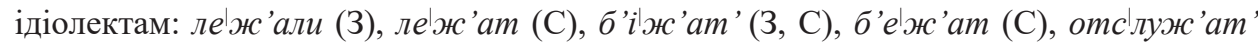
(3), що свідчить про збереження в острівному ареалі давніх консонантних рис середньонаддінпрянських говірок.

Ще одним маркером ідіолекту в українських переселенських говірках Башкирії $€$ вплив відмінювання прикметників м'якої групи на прикметники твердої групи, що виявляється в зміні флексійного [и] $\rightarrow$ [i] iз м'якшенням попереднього приголосного основи. Такі форми засвідчено переважно в ідіолектах Золотоношки; у мовленні одних діалектоносіїв ця риса простежується послідовно, в інших лише в окремих словоформах: во ни бу'ли ни_багат'іми л'уд'ми / n'росто йіх

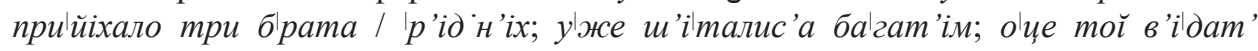
ко mop' $i \check{\imath}$ (3). Підкреслимо, що ця риса властива східним лівобережним говіркам середньонаддніпрянського діалекту (Гриценко 2007b, 602) та слобожанським говіркам (Шарпило, 44). У говірці Степанівки такі форми рідкісні: 'посл'е

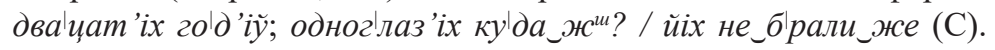

Аналіз лексикону, приманного ідіолекту окремої мовної особистості, дещо складніший, адже для цього має бути сформовано тематично зіставну джерельну базу дослідження, а під час записування матеріалу ми намагалися охопити якомога ширшу проблематику. Загалом же лексичними маркерами ідіолекту можуть бути лексеми, що засвідчують зв'язок із материнською говіркою. В окремих випадках використання таких слів мовцями може навіть спричиняти комунікативні невдачі в спілкуванні з мешканцями інших українських сіл у Башкирії: Гриша йа

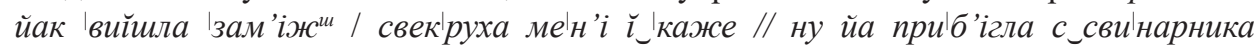

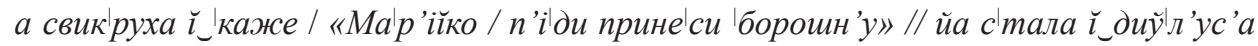

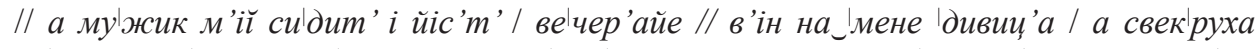

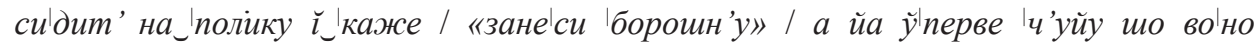

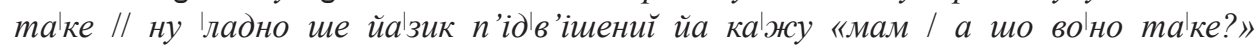
(3; Хижниченко Марія, 1934 р. н.). У цьому випадку протиставлено лексеми мука: борошно, ареальну опозицію яких узагальноукраїнському (і загальнослов' янському) контексті подає ЗЛА (ОЛА-ЛС 6, к. 11), хоч і на дуже укрупненій мережі. Але це випадки поодинокі; загалом 3 огляду на спільний материнський ареал досліджуваних говірок, можемо припустити, що таких лексичних маркерів (до 
яких, певна річ, не належать лексеми, пов'язані 3 традиційною народною культурою, що зберігаються в пам'яті лише окремих носіїв української мови) буде обмаль.

Отже, на тлі відносної одноманітності мовних рис говірок с. Золотоношка i c. Степанівка на рівні окремих ідіолектів простежено особливості, які властиві лише для мовлення конкретного носія говірки або, частіше, мають у мовленні конкретного носія говірки більший чи менший ступінь вияву. Здебільшого такі риси бувають варіантними навіть на рівні ідіолекту.

Маркери ідіолекту зазвичай мають ареальну прив'язку до конкретної мовної системи в материнському ареалі, здебільшого зберігаючи риси вихідних говорів і неоднаково виявляючись у різних носіїв говірки. Рідше - це набуті риси в новому функціональному середовищі і по-різному асимільовані мовцями з контактних мов (здебільшого російської).

\section{Скорочення}

3 - Золотоношка Стерлітамакського р-ну;

C - Степанівка Аургазинського р-ну, Республіка Башкортостан, РФ.

\section{Література}

АУМ, Атлас української мови [Atlas ukrainskoi movy], т. 1: Полісся, Наддніпрянщина і суміжні землі [Polissia, Naddniprianshchyna i sumizhni zemli], Київ 1984, т. 3: Слобожанщина, Донеччина, Нижня Наддніпрянщина, Причорномор'я та суміжні землі [Slobozhanshchyna, Donechchyna, Nyzhnia Naddniprianshchyna, Prychornomoria ta sumizhni zemli], Київ 2001.

Бабенко В.Я. [Babenko V.Yа.] (2011), Українці Башкортостану за чотири століття [Ukraintsi Bashkortostanu za chotyry stolittia], [в:] Українці Башкирї, т. 1: Дослідження i документи, Київ-Уфа, с. 9-45.

Бевзенко С.П. [Bevzenko S.P.] (1980), Украӥнська діалектологія [Ukrainska dialektologiia], Київ.

Гриценко П. [Hrytsenko Р.] (2007a), Ідіолект і текст [Idiolekt i tekst], [в:] Лінгвостилістика: об'єкт - стиль, мета - оцінка: Збірник наукових праць, присвячений 70-річчю від дня народження проф. С.Я. Срмоленко. Київ, с. 16-43.

Гриценко П.Ю. [Hrytsenko P.Yu.] (2007b), Середньонаддніпрянський говір [Serednonaddniprianskyi hovir], [в:] Українська мова. Енщиклопедія, вид. 3, Київ, с. 601-603.

Гриценко П.Ю. [Hrytsenko P.Yu.] (2007c), Слобожанський говір [Slobozhanskyi hovir], [в:] Українська мова. Енциклопедія, вид. 3, Київ, с. 631-632.

ГЧ, Говірки Черкащини. Збірник діалектних текстів [Hovirky Cherkashchyny. Zbirnyk dialektnykh tekstiw], Черкаси 2013.

Єрмоленко С.Я. [Yermolenko S.Yа.] (2007), Стиль індивідуальний [Styl indyvidualnyi], [в:] Українська мова. Енциклопедія, вид. 3, Київ, с. 676-677. 
Єрмоленко С.Я., Бибик С.П., Тодор О.Г. [Yermolenko S.Ya., Bybyk S.P., Todor O.Н.] (2001), Украӥнська мова. Короткий тлумачний словник лінгвістичних термінів [Ukrainska mova. Korotkyi tlumachnyi slovnyk linhvistychnykh terminiv], Київ.

Иванцова E.B. [Ivantsova E.V.] (2002), Феномен диалектной языковой личности [Fenomen dialektnoj yazy kovoj lichnosti], Томск.

Мартинова Г.I. [Martynova H.I.] (2003), Середньонаддніпрянський діалект. Фонологія i фонетика [Serednonaddniprianskyi dialekt. Fonolohiia i fonetyka], Черкаси.

ОЛА-ЛС 6, Общеславянский лингвистический атлас. Серия лексико-словообразовательная [Obshheslavyanskij lingvisticheskij atlas. Seriya leksiko-slovoobrazovatel'naya], вып. 6: Домашнее хозяйство и приготовление пищи [Domashnee xozyajstvo i prigotovlenie pish$h i]$, отв. ред. Т.И. Вендина [T.I. Vendina], Москва 2007.

Попов П.М. [Popov P.М.] (1999), До історії вивчення українського населення Башкирії [Do istorii vyvchennia ukrainskoho naselennia Bashkyrii], [в:] Завези од мене поклон в Україну... Фольклор украӥнців Башкортостану, Уфа.

Ставицька Л. [Stavytska L.] (2009), Про термін ідіолект [Pro termin idiolekt], „Українська мова", № 4, с. 3-17.

УСД, Українці. Східна діасnора. Атлас [Ukraintsi. Skhidna diaspora. Atlas], Київ 1992.

Фроляк Л.Д. [Froliak L.D.] (2002), Ідіолект як частина говірки [Idiolekt yak chastyna hovirky], „Лінгвістичні студіï”, вип.10, с. 206-210.

ЧНБ, Численность населения по населенным пунктам Республики Башкортостан по данным Всероссийской переписи населения 2010 года: статистический бюллетень [Chislennost' naseleniya po naselenny'm punktam Respubliki Bashkortostan po danny'm Vserossijskoj perepisi naseleniya 2010 goda: statisticheskij byulleten '], Уфа 2012.

Шарпило Б.А. [Sharpylo B.А.] (2013), Говірки Луганщиини в їх віднотенні до діалектної системи південно-східного наріччя украӥнської мови [Hovirky Luhanshchyny v yih vidnoshenni do dialektnoi systemy pivdenno-skhidnoho narichcha ukrainskoi movy], [в:] Шарпило Б.A. [Sharpylo B.A.] Вибрані прачі [Vybrani praci], Луганськ, с. 40-101. 